\title{
Application of Aporrectodea caliginosa to Mitigate the Waste and the Effects of Vermicompost on the Exomorphological Features of Phaseolus vulgaris
}

\author{
Rouf Ahmad Mir $\mathbb{D}^{1},{ }^{1}$ Sarita Shrivastava, ${ }^{1}$ Pragya Singh Pawaiya, ${ }^{2}$ and Hemant Samadhiya ${ }^{3}$ \\ ${ }^{1}$ Department of Zoology, Government Model Science College, Gwalior, 474011 MP, India \\ ${ }^{2}$ Jiwaji University, Gwalior, $474011 \mathrm{MP}$, India \\ ${ }^{3}$ School of Studies Zoology, Jiwaji University, Gwalior, India
}

Correspondence should be addressed to Rouf Ahmad Mir; roufbio24@gmail.com

Received 15 April 2021; Accepted 30 July 2021; Published 1 September 2021

Academic Editor: Suhaib Bandh

Copyright (c) 2021 Rouf Ahmad Mir et al. This is an open access article distributed under the Creative Commons Attribution License, which permits unrestricted use, distribution, and reproduction in any medium, provided the original work is properly cited.

\begin{abstract}
Vermin biotechnology is an eco-friendly technique and economically beneficent process to mitigate organic waste. India's agroindustrial sector contributes colossal wealth of plant materials in the form of compost. The present study aims to publicize soil healthiness and its plant growth supplying possessions further corroborating the use of organic amendments instead of fertilizers. Plastic replicates investigation is an exercise in eighteen replicates in which fifteen were soil amendment treatments: one triplicatecontrol, $0 \%$ vermicompost, $50 \%, 25 \%, 12.5 \%, 6.25 \%$, and $3.125 \%$ vermicompost of soil. Containers contained $2 \mathrm{~kg}$ soil each, in which seeds are sown, and the measurement of studied traits (length of shoot, length of internodes, flowers, leaves number and number of branches, and rate of germination) was noticed. The earthworms (Eudrilus eugeniae and Aporrectodea caliginosa) feed on waste like broiler droppings, the dung of sheep and cow, leaves, and decomposed wood and convert it into vermicompost, which required 72 days to extenuate the waste. Each setup was conducted on plastic containers, and there would be control and the test at respective experiments. Vermicompost was prepared; obviously, it contains better farming nutrients analyzed by different scientific methods and is very efficient for plant growth and other features. The main objective of the study was the effect of quality vermicompost produced by A. caliginosa on the exomorphology and rate of germination of Phaseolus vulgaris. Different ratios of vermicompost in respective replicates affect plant growth and external morphology, which is directly linked with nutrients present in treated and untreated soil. The outcomes suggested that vermicompost can be overworked as an efficacious biofertilizer.
\end{abstract}

\section{Introduction}

The engrossing rate of Aporrectodea caliginosa is moderate and required more time to convert the dung of sheep, cow, and broiler droppings into vermicast. This worm is used in vermicomposting as well and is native to Great Britain. The endogeic species Aporrectodea caliginosa [1] is a delegate of cultivable fields in temperate regions and is implicated as a pertinent model test species. Aporrectodea caliginosa is capable of outlasting in soils with abject organic matter $1.4 \%$ organic carbon [2] and furthermore moisture content. In abstemious agricultural soils, earthworm enlargement is swift at soil temperatures from 15 to $20^{\circ} \mathrm{C}$ while the soil moisture is near to field ability [3-6].These worms are used in excessive amounts to perform their function efficiently on waste like dung of animals, leaves and decomposed wood, etc. Worms are very significant to recycle different biodegradable waste in our surroundings.

The exorbitant application of chemical fertilizers in agriculture is an effect of matter. It exalts the level of pollutants in fruits and declines soil fertility and contamination of groundwater [7]. Replacement of chemical fertilizers by the organic amendments is very essential for the endurability of agriculture yield and retention of soil fertility [8]. The compost and vermicompost quality is the most important yardstick in reclamation of organic waste and application in 
agriculture as organic alterations; they can fit the nutriment exigence of agriculture crops $[9,10]$. Vermicompost is the outcome of organic matter degeneration through correlations between earthworms and microorganisms [11, 12]. Vermicompost not only the root of organic matter and nutrient but also promote microbial population, physical, living, and chemical properties of the soil $[13,14]$.

\section{Materials and Methods}

2.1. Waste Collection. The waste collection was done at our surroundings like dung of sheep and cows that were easily available, due to the good ratio of cattle stock present in Kulgam J\&K (UT), India. Broiler droppings were collected from the nearest poultry farm present in Kulgam district. Droppings plucked also were mixed with crushed powered wood, because they got dry when in contact with crushed powered wood and leaves as well, besides decomposed wood taken from the dense forest area.

2.2. Plastic Containers. The experiment was carried out in plastic bins; at least six plastic containers were used. Wastes were first weighed on a digital weighing machine and then put in containers. Predecomposition was done at least 15 days before complete bacterial decomposition occurs. After the predecomposition process occurs, then worms were poured on readily available waste in containers. Earthworms are present in local fields in Kulgam district J\&K (UT) India. Usually, 40 worms of weight $15 \mathrm{~g}$ were put in each container, and other triplicates contained 25 Eudrilus eugeniae.

2.3. Experimental Design. The experiment was conducted using Aporrectodea caliginosa or field worm in plastic containers $(10 \mathrm{~cm} \times 20 \mathrm{~cm} \times 12 \mathrm{~cm})$, and waste was kept on the net in a container to avoid worm escape and placed under the shed, to prevent any interruption of pests. And sometimes, these containers are put in room to imitate microclimatic conditions $[15,16]$. First experimental setup was conducted to convert waste into vermicompost; it took 72 days to convert $2 \mathrm{~kg}$ cow dung, $1 \mathrm{~kg}$ sheep dung, $1 \mathrm{~kg}$ predecomposed crushed wood waste and leaves, and $1 \mathrm{~kg}$ poultry droppings and setup was based on 3 replicates. $\mathrm{pH}=7.2$ and temperature $=25-29^{\circ} \mathrm{C}$ were detected before setup. During precomposting also called thermocomposting effectively inactivates pathogens [17] and averts the divulgence of earthworms to exalted temperatures in the course of the incipient thermophilic degree of microbial decomposition [18]. The experiment was conducted on the field after 15 days; predecomposition completed and then worms were put on the corner side of plastic containers; usually 40 adult worms start consuming the upper layer of waste. The worms brought from the field were stacked with mud; initially they got stagnant in mud; within few weeks, their population increases and started to consume waste. Regular watering was carried out to maintain proper moisture content and protect containers to get rid of ants and termites as well. In the containers that contained mixed waste, worms consumed that slowly and took more time for conversion, while it took less time in other containers that contained a single type of waste; the overall average time required was 72 days. Weekly monitoring to detect the number of eggs produced and count the number of worms formed during this entire period is shown in Table 1 .

2.4. Preparation of Vermicompost. Vermimanure was prepared in plastic trays with height $\times$ length $\times$ breadth dimensions of $10 \mathrm{~cm} \times 20 \mathrm{~cm} \times 12 \mathrm{~cm}$. The dimension of plastic try was length $20 \mathrm{~cm}$ and $12 \mathrm{~cm}$ in breadth and depth $10 \mathrm{~cm}$, respectively. A green net was placed at the base of the plastic try to restrict the earthworms going outside the plastic try and maintain moisture content as well; green net also helps to cover the try and avoid earthworm predators. The plastic tries were filled with different waste like cow dung, leaves, decomposed wood, poultry droppings, pigeon dropping, and sheep dung, respectively, in different quantity as well. At initial stage, mud water was sprinkled at random intervals. So that the medium prepared as an essential for growing earthworms and the suitable condition is very important for earthworm biology. At least 30-40 earthworms (Aporrectodea caliginosa and Eudrilus eugeniae) were introduced in the waste present in plastic try after the predecomposition process is over to avoid unnecessary heat, which occurs during microbial decomposition on the mixed waste. $3 \mathrm{~cm}$ thick layer of cow dung, poultry and pigeon droppings, crushed wood and leaves as well of respective weight is mentioned in Table 1. When mud water is sprinkled on this waste, at the initial stage Aporrectodea caliginosa (as shown in Figure 1) consumed less waste. When mud water is sprayed, their efficiency is modified and adopted in these media efficiently. Earthworm populations were also noticed in different replicates in mixed, only cow dung + sheep dung, sheep dung, respectively. After all these processes were done, harvesting was started on the 72nd day, and the earthworms were separated from vermimanure. The young worms and cocoons were separated from different replicates using $3 \mathrm{~mm}$ sieves. The vermicompost prepared by these worms contains macro and micronutrients as well [19].

Sample 1 contains different waste; all parameters were initially analyzed like temperature. $\mathrm{pH}$ was initially 7.6, and when vermicompost was prepared, $\mathrm{pH} 7.9$ was estimated. But the earthworm which consumed this mixed waste was Aporrectodea caliginosa (field worm); it takes extra 12 days to mitigate the mixed waste. In the case of sample 1, the vermicompost prepared from sample 1 is used mainly for the treatment to soils. It contains all nutrients in optimum level, better for plant development as well. The cow dung + S. dung consumed by Eudrilus eugeniae brought from Gwalior was introduced in Kulgam for vermicomposting purposes. The sheep dung consumed by Aporrectodea caliginosa took less than 60 days. In sample 2, exotic vermicomposting earthworms are used to mitigate the waste less than 60 days. The introduction of Aporrectodea caliginosa for vermicomposting mitigates all waste as well.

The best earthworms population was seen in sample 1 with good quantity vermimanure. In sample 2 , the worms introduced belong to temperate areas, so their adaptation was changed in a cold environment, as we know most 
TABLE 1: Earthworm species consumed waste and the changes monitored during this period.

\begin{tabular}{|c|c|c|c|c|c|c|c|}
\hline $\begin{array}{l}\text { Type } \\
\text { of waste }\end{array}$ & $\begin{array}{l}\text { No. of } \\
\text { eggs }\end{array}$ & $\begin{array}{l}\text { No. of } \\
\text { infant } \\
\text { worms }\end{array}$ & $\begin{array}{c}\text { Waste } \\
\text { consumed by } \\
\text { worm }\end{array}$ & $\begin{array}{l}\text { Days to } \\
\text { complete }\end{array}$ & $\begin{array}{l}\text { Initial } \\
\mathrm{pH} \text { of } \\
\text { waste }\end{array}$ & $\begin{array}{l}\text { Weight of } \\
\text { waste }(\mathrm{kg})\end{array}$ & $\begin{array}{l}\text { No. of adults } \\
\text { (earthworms) }\end{array}$ \\
\hline $\begin{array}{l}\text { Sample } 1 \\
\text { Mixed waste, cow dung, } \\
\text { sheep dung, decomposed wood, } \\
\text { powered wood, broiler droppings, } \\
\text { pigeon droppings, leaves }\end{array}$ & $\begin{array}{l}40 \text { eggs } \\
\text { recorded }\end{array}$ & 20 & $\begin{array}{c}\text { Aporrectodea } \\
\text { Caliginosa }\end{array}$ & 72 days & 7.6 & 5 & 150 \\
\hline $\begin{array}{l}\text { Sample } 2 \\
\text { Cow dung, sheep dung }\end{array}$ & 25 & 25 & $\begin{array}{l}\text { Eudrilus } \\
\text { eugeniae }\end{array}$ & 60 & 7.8 & 5 & 100 \\
\hline $\begin{array}{l}\text { Sample } 3 \\
\text { Sheep dung }\end{array}$ & 20 & 15 & $\begin{array}{l}\text { Aporrectodea } \\
\text { caliginosa }\end{array}$ & 60 & 7.2 & 5 & 88 \\
\hline
\end{tabular}

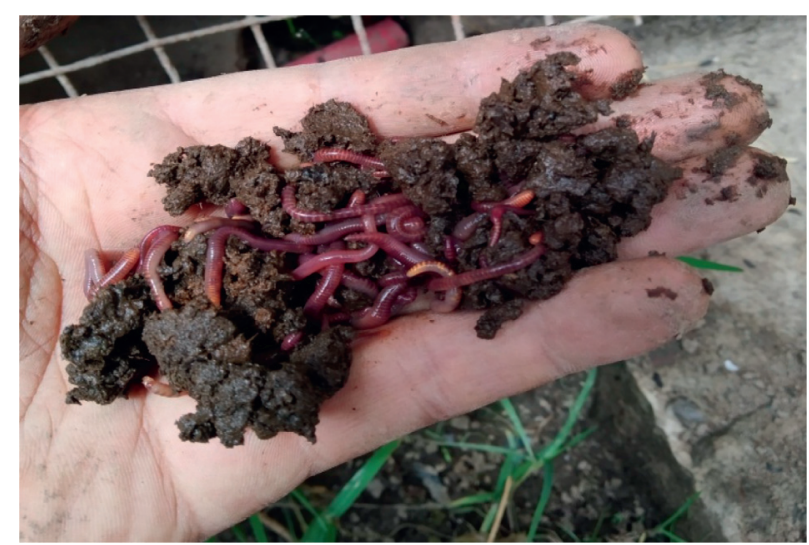

Figure 1: Number of Aporrectodea caliginosa.

suitable food for earthworms is cow dung. Little bit of changes occur in vermicompost prepared from Eudrilus eugeniae, providing room temperature to sample 2 and sample 3 to avoid any disfigure and experimental loss; in sample 3, worms used were Aporrectodea caliginosa. Table 2 indicates the quality vermicompost produced have better chemical composition; the number of eggs had been recorded in sample 2 which contain cow dung, but the temperature was below $20^{\circ} \mathrm{C}$. The earthworms in sample 2 consume waste below 60 days.

The vermicompost's chemical and physical profile indicates that it contains all ingredients in optimum amount as shown in Table 2; besides this its density is $0.6-0.7$ and no odour and macronutrients in a good amount prescribed by Horticulture Department of Govt. of India; besides this particle size is almost $88 \%$. Normal moisture content is acceptable between $50 \%$ and $60 \%$. Total nitrogen was estimated by the Kjeldahl method; other nutrients were analyzed by spectrophotometer:

Sample $1=$ vermicompost (mixed waste: cow dung, sheep dung, decomposed wood, powered wood, broiler droppings, pigeon droppings, leaves), $\mathrm{WHC}=$ water-holding capacity, and $\mathrm{OC}=$ organic carbon.

Usually in this work, whole experiment was conducted by using Aporrectodea caliginosa as an experimental worm, consuming waste $3 \mathrm{~cm}$ at least 72 days while Eudrilus eugeniae feed on cow dung and sheep dung as well. It took under 60 days to mitigate $3 \mathrm{~cm}$ thickness waste to complete the process. The vermicompost produced had met with secretions released from the gut of earthworms; it makes vermicasts more nutrient-rich. Table 3 shows the degradation process of two earthworms and the period time taken to complete the harvest of vermicompost.

2.5. Treatment. The experiment was conducted when quality vermicompost is prepared from Aporrectodea caliginosa and Eudrilus eugeniae. The seeds of mesh beans were taken from the Department of Agriculture Kulgam Jammu \& Kashmir and were sown on each replicate with vermicompost-treated soil and control without vermicompost. The vermicomposting was done in plastic containers and sieving the product and then used in 18 replicates which contain $4 \mathrm{~kg}$ soil each. This experiment was carried out on an open field; 18 plastic containers were used for the study. Beans need full sun and deep, rich, well-drained soil to grow them best. Creating the bean pod takes photosynthesis energy along with a generous water supply; plants use approximately $1 / 2$ inch of water each day during the blossom and pod growth period. Figure 2 displays the normal growth of Phaseolus vulgaris present in a container.

Table 4 depicts 18 replicates utilized in the experiment on which three plastic containers were used as control while 15 were put to use in experiment and different proportions of vermicompost, which was applied for treating the soil. The number of results was acquired when control and experiment data have collaborated. 
TABle 2: Chemical profile of vermicompost made by Aporrectodea caliginosa (field worm).

\begin{tabular}{lccccccc}
\hline Containers & $\mathrm{pH}$ & Moisture (\%) & WHC (\%) & OC (\%) & Total N (\%) & Total P (\%) & Total K (\%) \\
\hline Sample 1 & 7.5 & 57.11 & 82.54 & 39.21 & 1.40 & 0.58 & 0.99 \\
Sample 2 & 7.3 & 40.11 & 41.23 & 29.02 & 1.20 & 0.48 & 0.95 \\
Sample 3 & 8.1 & 42.24 & 39.99 & 22.02 & 1.09 & 0.21 & 0.28 \\
\hline
\end{tabular}

TABLE 3: Waste consumed by earthworms in different replicates.

\begin{tabular}{lccccc}
\hline Container & $\begin{array}{c}\text { Earthworm } \\
\text { species }\end{array}$ & $\begin{array}{c}\text { Date and } \\
\text { month of release }\end{array}$ & Day of harvest & $\begin{array}{c}\text { Amount of } \\
\text { earthworms } \\
\text { released in kg }\end{array}$ & Amount which was completely ready (cm) \\
\hline Sample 1 & Aporrectodea caliginosa & $11 / 5 / 2020$ & 72 days & 40 adult worms & 3 \\
Sample 2 & E. eugeniae & $11 / 5 / 2020$ & Under 60 days & 25 worms & 3 \\
Sample 3 & Aporrectodea caliginosa & $11 / 5 / 2020$ & 72 days & 40 adult worms & 3 \\
\hline
\end{tabular}

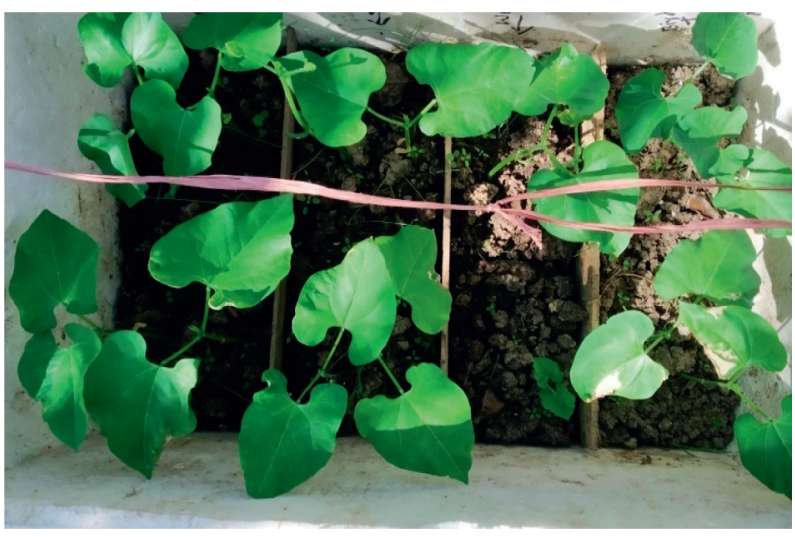

FIgURe 2: Phaseolus vulgaris (mesh bean plants).

TABLE 4: Application of vermicompost used in different replicates.

\begin{tabular}{|c|c|c|c|c|}
\hline Containers & Soil $(\mathrm{kg})+$ Vcompost & Vcompost $(\mathrm{kg}-\mathrm{g})+$ soil & Vermi-compost + soil & $\%$ of VC \\
\hline Control & $4 \mathrm{~kg}$ soil & $4 \mathrm{~kg}$ soil & $4 \mathrm{~kg}$ soil & 0 \\
\hline Experimental & Replicate (1) & Replicate (2) & Replicate (3) & \\
\hline 1st container & $\mathrm{S} 4 \mathrm{~kg}+\mathrm{VC} 2 \mathrm{~kg}$ & $\mathrm{~S} 4 \mathrm{~kg}+\mathrm{VC} 2 \mathrm{~kg}$ & $\mathrm{~S} 4 \mathrm{~kg}+\mathrm{VC} 2 \mathrm{~kg}$ & 50 \\
\hline 2nd container & $\mathrm{S} 4 \mathrm{~kg}+\mathrm{VC} 1 \mathrm{~kg}$ & $\mathrm{~S} 4 \mathrm{~kg}+\mathrm{VC} 1 \mathrm{~kg}$ & $\mathrm{~S} 4 \mathrm{~kg}+\mathrm{VC} 1 \mathrm{~kg}$ & 25 \\
\hline $3 r d$ container & $\mathrm{S} 4 \mathrm{~kg}+\mathrm{VC} 500 \mathrm{~g}$ & $\mathrm{~S} 4 \mathrm{~kg}+\mathrm{VC} 500 \mathrm{~g}$ & $\mathrm{~S} 4 \mathrm{~kg}+\mathrm{VC} 500 \mathrm{~g}$ & 12.5 \\
\hline 4th container & $\mathrm{S} 4 \mathrm{~kg}+\mathrm{VC} 250 \mathrm{~g}$ & $\mathrm{~S} 4 \mathrm{~kg}+\mathrm{VC} 250 \mathrm{~g}$ & $\mathrm{~S} 4 \mathrm{~kg}+\mathrm{VC} 250 \mathrm{~g}$ & 6.25 \\
\hline 5th container & $\mathrm{S} 4 \mathrm{~kg}+\mathrm{VC} 125 \mathrm{~g}$ & $\mathrm{~S} 4 \mathrm{~kg}+\mathrm{VC} 125 \mathrm{~g}$ & $\mathrm{~S} 4 \mathrm{~kg}+\mathrm{VC} 125 \mathrm{~g}$ & 3.125 \\
\hline
\end{tabular}

\section{Statistical Analysis}

The data obtained from morphological parameters were subjected to statistical analysis. The 1st, 2nd, and 3rd weeks' data of shoot length were given as average shoot length and standard error, standard deviation. The differences between the experimental groups and controls were statistically analyzed. The level of significance was set at $P<0.05$.

\section{Results}

4.1. Effects of Vermicomposts in Soil Present in Replicates. The soil in replicates was weighed, and then the soil was treated with a different ratio of vermicompost prepared by
Aporrectodea caliginosa. The amounts of nitrate in soil from replicates treated with vermicompost were significantly greater than in soils from untreated soil. $2 \mathrm{~kg}$ soil is present in each replicate whether control or experiment, and vermicompost is added in each replicate in $0 \mathrm{~kg}$; vermicompost is added in controlled replicate and $2 \mathrm{~kg}, 1 \mathrm{~kg}, 500 \mathrm{~g}, 250 \mathrm{~g}$, and $125 \mathrm{~g}$ are added in experimental replicates, respectively. Replicates treated with vermicompost of different weight had significantly more microbial biomass $\mathrm{N}$ than replicates treated without vermicompost shown in Table 4 . There was a trend for greater dehydrogenase activity to occur in soils treated with vermicomposts, compared to that in soils treated with $0 \% \mathrm{~kg}$ vermicompost. Particularly soils treated with mixed cow manure had significantly more 
dehydrogenase activity than soils treated with $0 \%$ vermicompost. The replicates treated with different quantities of vermicompost as shown in Table 4 like $2 \mathrm{~kg}, 1 \mathrm{~kg}, 500 \mathrm{~g}$, $250 \mathrm{~g}$, and $125 \mathrm{~g}$ have a different ratio of phosphate, potassium, and nitrogen as well and their effect on the plant also varies greatly than soils treated with $0 \%$ vermicompost. The 3 rd replicate which contained $500 \mathrm{~g}$ vermicompost has more sophisticated outcomes regarding plants' external morphology than other treatments of vermicompost.

In a nutshell, amounts of nitrates in different replicates did not vary significantly among treatments. But the replicates treated with good quality vermicompost prepared from Aporrectodea caliginosa and traditional compost had significantly more microbial biomass $\mathrm{N}$ than those replicates treated with $0 \mathrm{~kg}$ vermicompost. Adequate amounts of nutrients are definitely present in replicates that have more quantity of vermicompost. But the reason as per Table 4 shows that $2 \mathrm{~kg}$ and $1 \mathrm{~kg}$ vermicompost replicates in which nutrient quantity is more, the mesh bean plants show more growth and there is the probability of logging problem is associated with the plants. While the other two replicates contained $250 \mathrm{~g}$ and $125 \mathrm{~g}$ of vermicompost, plants show stunted growth with decreased yield as well.

\subsection{Growth and Yield. Growth and yields of Phaseolus} vulgaris are significantly good in soils treated with vermicompost compared to those soils which have $0 \%$ vermicompost yields less. The better outcome is obtained when $2 \mathrm{~kg}$ soils was treated with $500 \mathrm{~g}$ vermicompost; average shoot was maximum but standard error was less than rest of treatments. The other containers treated with different doses of vermicompost; their average growth shoot growth is slightly more or less than container, but their standard error is slightly more than other treated containers as well as control. As per standard analysis of shoot length of 1st, 2nd, and 3rd weeks is concerned, when treated soils are compared with each other, more value of standard error occurs, but 3rd container showed 95\% accuracy in terms of shoot length, number of leaves, flowers, and pod yield as well. To enhance efficient flowering because the experiment was conducted in open field, temperature was not favorable usually in autumn. To avoid this hindrance, green house is constructed under which all replicates were put, with the consequences of efficient flowering and later pods formation occurring, respectively. Soils treated with different amounts of vermicompost; the controlled container that was with $0 \%$ vermicompost had less yield and external structure of their mature pods was not fit for market while those plants are treated with vermicompost; mostly the 3 rd container had good yield and was fit for market. The data are present in Table 5 during 4th week, 5th week, and 6th week; great variation was shown when control is compared with treated containers in yield, shoot length, flowers leaves, and branches; all these external parameters were seen in vermicompost-treated soils. When treated containers are compared with each other, in terms of yield that was seen in 3rd container, all parameters fit in containers which contained vermicompost $500 \mathrm{~g}$.

\subsection{Measurement of Plant Growth Parameters}

4.3.1. Length of the Shoot. There is a significant difference in shoot length between control and treated plants. Length of the shoot at the beginning of the 1st week and 3rd week changes, respectively, and based on total average length and standard error, our results show 95\% correctness. A considerable increase in shoot length was recorded in treated plants; when compared to control plants shoot length to vermicompost-treated plants $50 \%, 25 \%, 12.5 \%, 6.25 \%$, $3.125 \%$ was significantly higher than in control (12.45) plants, as shown in Tables 6-8.

ASL stands for average shoot length; if the average shoot length is more and the value of standard error is less, the results show normalcy. This fits all in container 3 shown in Table 6.

As per data obtained from second week ASL and standard error in case of control shoot length is less but standard error is also less, 3rd container ASL is more but standard error is less; hence, our data is accurate, as shown in Table 7. ASL stands for average shoot length.

Similarly, all results suit in 3rd container, in Table 8. Shoot length shows acceptable result in vermicompost $12.5 \%$, and external morphological and flowers, leaves are significantly well in containers when comparison was done. Average variability in data shows how far each score lies from the average value.

4.3.2. Length of Internodes. Usually, gibberellic acid is used to increase internodes length. Usually, intermodal length was seen in a plant which was treated with $50 \%$ vermicompost (maximum $(2.88 \mathrm{~cm}$ ), followed by $25 \%$ length (2.28), but the moderate length of internodes was seen in soil treated with $12.5 \%$ vermicompost (2.16).

4.3.3. Number of Leaves. The number of leaves from germination stage to mature stage shows variations and different containers had a different amount of vermicompost like $50 \%, 25 \%, 12.5 \%, 6.25 \%$, and $3.125 \%$ treated soil, showing a maximum number of leaves, respectively (Figure 3). Definitely, the maximum number of leaves was present on plants treated with $2 \mathrm{~kg}$ vermicompost but shows scarcity in yield. But appropriate outcomes would be analyzed on plants treated with $500 \mathrm{~g}$ vermicompost, shown in Table 5. Other replicates such as 4 th replicate treated with $6.25 \%$ vermicompost leave size was normal and plant shows optimum growth, but results comparison like the number of leaves show variation. The minimum number of leaves was recorded in control which contained no vermicompost as well shown in Table 5.

The data present in Table 5 was analyzed, when climatic conditions were not favorable for flowering then greenhouse arrangement was constructed, put all 18 replicates under and normal flowering and pod formation occurs, all variations can be seen in Table 5. More yields were obtained from vermicompost-treated soil than control containers without vermicompost. In between vermicompost-treated containers, best flowering and pods formation occurs in vermicompost-treated soil of $12.5 \%$. 
TABLe 5: Exomorphological parameters obtained during the 4th, 5th, and 6th weeks.

\begin{tabular}{|c|c|c|c|c|c|c|}
\hline & Total leaves & Total branches & Total flowers & Avg. leaves & Avg. branches & Avg. flowers \\
\hline Control & 80 & 24 & 108 & 26.66 & 8 & 36 \\
\hline Exp. Con. 1st & 200 & 43 & 179 & 66.66 & 14.33 & 59.66 \\
\hline Con. 2nd & 192 & 42 & 178 & 64 & 14 & 59.33 \\
\hline Con. 3rd & 190 & 44 & 180 & 63.33 & 14.66 & 60 \\
\hline Con. 4th & 160 & 34 & 159 & 53.33 & 11.33 & 53 \\
\hline Con. $5^{\text {th }}$ & 140 & 33 & 140 & 46.66 & 11 & 46.66 \\
\hline
\end{tabular}

TABle 6: The shoot length of a plant at the first week.

\begin{tabular}{|c|c|c|c|c|c|c|c|}
\hline & Containers & ASL & SD & SE & CI (95\%) & VC (\%) & Rate ger. (\%) \\
\hline$\longrightarrow$ & Control & 3.41 & 1.24 & 0.50 & 1.30 & 0 & 75 \\
\hline \multirow[t]{5}{*}{ Experiment } & 1st container & 4.75 & 1.04 & 0.52 & 1.65 & 50 & 75 \\
\hline & 2nd container & 4.4 & 1.47 & 0.65 & 1.83 & 25 & 75 \\
\hline & 3rd container & 3.9 & 0.96 & 0.43 & 1.19 & 12.5 & 75 \\
\hline & 4 th container & 3.83 & 1.04 & 0.60 & 2.58 & 6.25 & 75 \\
\hline & 5th container & - & - & - & - & 3.125 & 0 \\
\hline
\end{tabular}

TABLE 7: Shoot length at the second week.

\begin{tabular}{|c|c|c|c|c|c|c|c|}
\hline & Containers & ASL & $\mathrm{SD}$ & SE & CI $(95 \%)$ & Days & VC (\%) \\
\hline & Control & 9.53 & 0.97 & 0.28 & 0.61 & 14 & 0 \\
\hline Experiment & 1st container & 15.6 & 2.32 & 0.67 & 1.47 & 14 & 50 \\
\hline & 2nd container & 12.6 & 1.67 & 0.48 & 1.06 & 14 & 25 \\
\hline 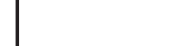 & 3rd container & 15 & 1.32 & 0.30 & 0.84 & 14 & 12.5 \\
\hline & 4th container & 12.2 & 1.04 & 0.38 & 0.66 & 14 & 6.25 \\
\hline$\downarrow$ & 5 th container & 11.8 & 1.71 & 0.49 & 1.08 & 14 & 3.125 \\
\hline
\end{tabular}

4.3.4. Maturity after Blooms. The experimental fieldwork was conducted in September and October months where the conditions of weather is not much favorable; so to avoid this barrier, the mesh bean plants was put under greenhouse for 20 days to occurred green pods on each plant as soon as the blooms drop and grow rapidly under greenhouse. Slender pods must be ready within 9 days, while it may take 15 extra or more for the pods to fill completely. Checking the pods daily insures that they do not become overgrown and toughen. Beans need full sun and deep, rich, well-drained soil to grow their best. Creating the bean pod takes photosynthesis energy along with a generous water supply; plants use approximately $1 / 2$ inch of water each day during the blossom and pod growth period.

4.3.5. Number of Branches. During the experimental period, the number of branches was increased in all the treated plants when compared to the control plants at the end of the 5 th week. The maximum number of branches was recorded in vermicompost $50 \%, 25 \%, 12.5 \%, 6.25 \%$, and $3.125 \%$ (Figure 3). The number of branches was less significant in the control plants (Figure 3 ). NPK percentage in vermicompost

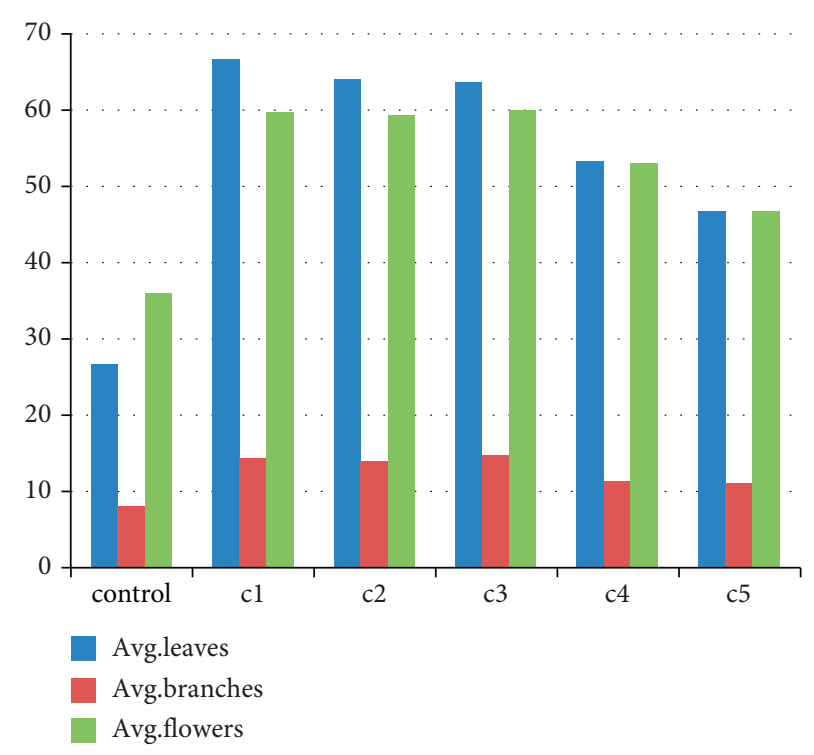

FIgURE 3: The overall average morphology of Phaseolus vulgaris. 
TABLE 8: Shoot length at the 3rd week.

\begin{tabular}{|c|c|c|c|c|c|c|c|}
\hline & Containers & ASL & $\mathrm{SD}$ & SE & CI $(95 \%)$ & Days & $\mathrm{VC}(\%)$ \\
\hline & Control & 12.45 & 1.03 & 0.29 & 0.65 & 21 & 0 \\
\hline \multirow{5}{*}{ Experiment } & 1st container & 26 & 1.70 & 0.49 & 1.08 & 21 & 50 \\
\hline & 2nd container & 24.6 & 1.32 & 0.38 & 0.84 & 21 & 25 \\
\hline & 3rd container & 21.10 & 1.60 & 0.28 & 1.02 & 21 & 12.5 \\
\hline & 4th container & 18.60 & 1.10 & 0.31 & 0.69 & 21 & 6.25 \\
\hline & 5th container & 15.92 & 1.21 & 0.35 & 0.77 & 21 & 3.125 \\
\hline
\end{tabular}

is seen in Table 2. The minimum NPK percentage was observed in the control soil samples, $\mathrm{N}(0.06), \mathrm{P}(0.002)$, and $K(0.03)$. The number of branches was seen in vermicompost-treated soils, but appropriate results were seen in 3rd replicate vermicompost which contained $500 \mathrm{~g}$ vermicompost.

Table 5 explains external parameters of different weeks; aggregated data was collected and a number of leaves, flowers, and branches of control as well as treated soils, show variations with each other; also there occurred differences in parameters among treated plants as well (Figure 3). As statistical tool applied on shoot length shows the shoot length is more and standard error has less value is acceptable and $5 \%$ chances of experimental inaccuracy. Similarly, the parameters like leaves, flowers, and branches show moderate outcomes in vermicompost-treated soil of $12.5 \%$.

Figure 3 indicates the average number of flowers, branches, and leaves. In 3rd container (c3), all columns touch line 60 while $\mathrm{cl}$ container shows that the number of leaves was more but the other two parameters show the slight decline and another factor which indicates its growth, vermicompost quantity is more while in case of 3rd container, all exomorphological characteristics are perfect and vermicompost amount was moderate usually $12.5 \%$.

\section{Discussion}

The enlargement of mesh plants (Phaseolus vulgaris) was built to be notably increased in plants treated with vermicompost. Plants treated with $50 \%, 25 \%, 12.5 \%, 6.25 \%$, and $3.125 \%$ of different replicates showed increased shoot length compared to plants treated with $0 \%$ vermicompost. An investigation conducted by [20] proclaimed the advantages of vermicompost as cover media to boost seed germination, seedling growth, and productivity of plants. To add organic waste to the soil in the form of vermicompost and vermiwash increases the yield and growth of plants. The experiment was conducted at an open place; both the waste of cassava peel and guava leaves were mixed or vermicompost prepared from poultry droppings. Mba (1983) noted more shoot biomass and marked up seed yields of cowpeas in rejoinder to vermicompost [21]. Examined straight uses of vermicomposts, created from sewage sludge to soils and noted a larger growth index of garden cress (Lepidium sativum), in vermicomposttreated soils, compared with those soils where no use of vermicompost occurred. The present study deals with soil treated $50 \%, 25 \%, 12.5 \%, 6.25 \%$, and $3.125 \%$ showing good growth than control which contained no vermicompost [22]. It was reported that the use of vermicompost obtained from grape marc, which was cover under grapevines and spread with straw and paper mulches enhanced the productivity of grapes variety by up to $55 \%$. The outcomes in the present endeavor are in correspondence with earlier investigations [23]. An amplification in the acquiesce of indubitable vegetable crops such as brinjal, okra, and tomato has been recorded by [24], respectively. Tritium aestivum plants are treated with vermimanure, plants' morphology is modified like the length of the plant, number of leaves, early ear heading, and dry matter of each plant was endowed to be modified when compared with control plants. The appearance of tomato, cabbage, and radish sapling was important in vermicomposted soil than in thermophilically composted animal waste [12]. Organic biofertilizers contain a rich amount of nutrients which are very beneficial for plant maintenance. The nutrients like NPK content present in vermicompost-treated soil were found to improve when compared with other compost treated soil [25].

The byproducts of microbial activities may include polysaccharides that are involved directly in the aggregation of soil particles, which could also have some influence on plant growth. It is also possible that humic acids in the vermicomposts used in the experiment could also have direct positive influences on the growth and yields of the mesh beans. In laboratory and greenhouse experiments by [26], definitive evidence of the positive growth effects of humic acids, extracted from cattle manure and food waste vermicomposts, was demonstrated. In their experiments, a range of doses of humic acid were extracted from vermicomposts acids by classic acid/alkali fractionation [27] and applied to tomato and cucumber seedlings grown in a soil-less medium.

References $[28,29]$ concluded that the growth responses were due either to the ability of humic acids to have hormone-like effects on plant growth or because the humic acids may have plant growth, regulators adsorbed onto them, and that these influenced the growth. Their hypothesis was confirmed by an investigation by [29], which identified auxin groups incorporated in humic acids that had been extracted from cattle manure vermicompost. The effects of humic acid applications to maize plants resulted in increased growth of the maize roots and stem which they attributed to the humic/auxin combination. It seems likely that humic acids produced in the vermicomposts used in our experiment might have also increased growth and yields of mesh beans (Phaseolus vulgaris). 


\section{Conclusions}

The results of this study showed that $12.5 \%$ or $500 \mathrm{~g}$ vermicompost-treated showed great potential to increase the growth of the bean plant and improved soil quality. The study positively highlights the importance of organic farming; therefore, vermicompost may be put to good use as a natural fertilizer for cereals and vegetable crops for increased production and for sustainable agricultural systems. The NPK was more in vermicompost-treated soils and hence made soil healthy. In our experiment, the amount of nitrogen present in the soil is quite low than vermicomposttreated soils; it was observed by many workers when earthworms consumed waste the amount of nitrogen will decrease with the passage of time but still remains nitrogen in vermicompost and also contains enzymes, hormones, vitamins, and other minerals as well. Besides this, phosphate and potassium also present in vermicompost-treated soils play a crucial role in plant growth and flowering processes as well. Results obtained when triplicate as control is without vermicompost shows great variation as compared with triplicates treated with different $\%$ of vermicompost like $50 \%, 25 \%, 12.5 \%, 6.5 \%$, and $3.125 \%$, respectively. Among these triplicates treated with vermicompost, the better result was found in $6.5 \%$ vermicompost-treated soil while others show a slight difference in flowering, pods decline, shoot length, and number of leaves; some triplicates of experimental like 50\% and 25\% show enormous shoot length but less yield and plants in these replicates show logging when regular watering was done, while other plants dehisced due to excess available of NPK. The replicates of $\%$ of vermicompost is $6.25 \%$ and $3.125 \%$ of treated soils show growth less than $500 \mathrm{~g}$ replicate and flowering, number of pods as well and leaves was so much healthy as compared to $12.5 \%$ vermicompost-treated soils. Overall as per the results obtained the better yield and normal exomorphological characters were obtained from soil treated with $500 \mathrm{~g}$ vermicompost prepared by Aporrectodea caliginosa.

\section{Data Availability}

The data that support the findings of this study are available from the corresponding author upon reasonable request.

\section{Conflicts of Interest}

The authors declare no conflicts of interest regarding the publication of this paper.

\section{Acknowledgments}

This research was made possible with the support of Dr. O.P. Agrawal, Former Vice-Chancellor of Jiwaji University, Gwalior. The authors are grateful to Dr. S. K. Singh, Senior Soil Scientist, of KVK Agricultural Centre, Gwalior. Also, they are grateful to Dr. Rouf Ahmad Bhat, Assistant Professor, Department of Environmental Science, SP College, Srinagar, Jammu Kashmir (UT).

\section{References}

[1] J. C. Savingy, "Memoire sur les," in Analyse des travaux de I'Academia royale des sciences pendent I' anee 1821,partie physique, M. Cuvier and G. Baron, Eds., Mem., Acad., Sci., Inst., Fr., (HIST.), France, 1826.

[2] J. P. McDaniel, M. E. Stromberger, K. A. Barbarick, and W. Cranshaw, "Survival of Aporrectodea caliginosa and its effects on nutrient availability in biosolids amended soil," Applied Soil Ecology, vol. 71, pp. 1-6, 2013.

[3] H. G. Baker and W. A. Whitby, "Soil pH preferences and the influences of soil type and temperature on the survival and growth of Aporrectodea longa (Lumbricidae)," Pedobiologia, vol. 47, no. 5, pp. 745-753, 2003.

[4] M. Holmstrup and H. P. Krogh, Effects and Risk Assessment of Linear Alkylbenzene Sulfonates in Agricultural Soil. 3. Sublethal Effects on Soil Invertebrates, 2009.

[5] L. A. Wever, T. J. Lysyk, and M. J. Clapperton, “The influence of soil moisture and temperature on the survival, aestivation, growth and development of juvenile Aporrectodea tuberculata (Eisen) (Lumbricidae)," Pedobiologia, vol. 45, no. 2, pp. 121-133, 2001.

[6] Q. Xu and B. Huang, "Growth and physiological responses of creeping bentgrass to changes in air and soil temperatures," Crop Science, vol. 40, no. 5, pp. 1363-1368, 2000.

[7] T. Hernandez, I. J. Moreno, and F. Costa, "Influence of sewage sludge application on crop yields and heavy metal availability," Soil Science and Plant Nutrition, vol. 37, no. 2, pp. 201-210, 2010.

[8] S. Sagar, C. B. Hedley, K. M. Giddens, and G. J. Salt, "Influence of soil phosphorus status and nitrogen addition on carbon mineralization from (Sup. 14) C-Labelled glucose inpasturesoils," Biology and Fertility of Soils, vol. 32, pp. 209-216, 2000.

[9] S. P. Kowalski, R. V. Ebora, R. D. Kryder, and R. H. Potter, "Transgenic crops, biotechnology and ownership rights: what scientists need to know," The Plant Journal, vol. 31, no. 4, pp. 407-421, 2002.

[10] S. Mavaddati, M. H. Kianmehr, I. Allahdadi, and G. R. Chegini, "Preparation of pellets by urban waste compost," International Journal of Environmental Research, vol. 4, no. 4, pp. 665-672, 2010.

[11] N. Q. Arancon, C. A. Edwards, P. Bierman, C. Welch, and J. D. Metzger, "Influences of vermicomposts on field strawberries: 1. Effects on growth and yields," Bioresource Technology, vol. 93, no. 2, pp. 145-153, 2004.

[12] C. A. Edwards and J. E. Bater, "The use of earthworms in environmental management," Soil Biology and Biochemistry, vol. 24, no. 12, pp. 1683-1689, 1992.

[13] R. Albiach, R. Canet, F. Pomares, and F. Ingelmo, "Microbial biomass content and enzymatic activities after the application of organic amendments to a horticultural soil," Bioresource Technology, vol. 75, no. 1, pp. 43-48, 2000.

[14] R. Baziramakenga, R. R. Lalande, and R. Lalande, "Effect of de-inking paper sludge compost application on soil chemical and biological properties," Canadian Journal of Soil Science, vol. 81, no. 5, pp. 561-575, 2001.

[15] A. B. Azizi, M. P. M. Lim, Z. M. Noor, and N. Abdullah, "Vermiremoval of heavy metal in sewage sludge by utilising Lumbricus rubellus," Ecotoxicology and Environmental Safety, vol. 90, pp. 13-20, 2013.

[16] A. B. Azizi, Z. M. Noor, T. D. S. Jaime, A. Noorlidah, and A. J. Adi, "Vermicomposting of sewage sludge by Lumbricus rebullus using spent mushroom compost as feed material: 
effect on concentration of heavy metals," Biotechnology and Bioprocess Engineering, vol. 16, pp. 1036-1043, 2011.

[17] J. Nair, V. Sekiozoic, and M. Anda, "Effect of pre-composting on vermicomposting of kitchen waste," Bioresource Technology, vol. 97, no. 16, pp. 2091-2095, 2006.

[18] T. Loh, Y. C. Lee, J. B. Liang, and D. Tan, "Vermicomposting of cattle and goat manures by Eisenia foetida and their growth and reproduction performance," Bioresource Technology, vol. 96, no. 1, pp. 111-114, 2005.

[19] S. A. Ismail, The Earthworm Book, Other India Press, Mapusa, Goa, India, 2005.

[20] R. Atiyeh, S. Lee, C. Edwards, N. Arancon, and J. Metzger, "The influence of humic acids derived from earthwormprocessed organic wastes on plant growth," Bioresource Technology, vol. 84, no. 1, pp. 7-14, 2002.

[21] G. Masciandaro, B. Ceccanti, and C. Garcia, "Soil agro-ecological management: fertirrigation and vermicompost treatments," Bioresource Technology, vol. 59, no. 2-3, pp. 199-206, 1997.

[22] J. C. Buckerfield and K. A. Webster, Worm-Worked Waste Boosts Grape Yields: Prospects for Vermicompost Use in Vineyards, ScienceOpen, Inc., Boston, MA, USA, 1998.

[23] S. B. Agrawal, A. Singh, and G. Dwivedi, "Effect of vermicompost, farm yard manure and chemical fertilizers on growth and yield of wheat (Triticum aestivum)," Plant Archives, vol. 3, no. 1, pp. 9-14, 2003.

[24] S. K. Sinha and J. C. White, "Assay-dependent phytotoxicity of nanoparticles to plants," Environmental Science \& Technology, vol. 43, no. 24, pp. 9473-9479, 2009.

[25] A. A. Ansari and S. A. Ismail, "Relamation of sodic soils through vermitechnology," Pakistan Journal of Agricultural Research, vol. 21, pp. 92-97, 2008.

[26] R. M. Atiyeh, N. Q. Arancon, C. A. Edwards, and J. D. Metzger, "The influence of earthworm-processed pig manure on the growth and productivity of marigolds," Bioresource Technology, vol. 81, pp. 103-108, 2001.

[27] M. M. Valdrighi, A. Pera, M. Agnolucci, S. Frassinetti, D. Lunardi, and G. Vallini, "Effects of compost-derived humic acids on vegetable biomass production and microbial growth within a plant (Cichorium intybus)-soil system: a comparative study," Agriculture, Ecosystems \& Environment, vol. 58, no. 23, pp. 133-144, 1996.

[28] N. Q. Arancon, S. Lee, C. A. Edwards, and R. Atiyeh, "Effects of humic acids derived from cattle, food and paper-waste vermicomposts on growth of greenhouse plants," Pedobiologia, vol. 47, no. 5-6, pp. 741-744, 2003.

[29] L. P. Canellas, F. L. Olivares, A. L. Okorokova, and A. R. Facanha, "Humic acids isolated from earthworm compost enhance root elongation, lateral root emergence, and plasma H+-ATPase activity in maize roots," Plant Physiology, vol. 130, pp. 1951-1957, 2000. 